\title{
Effect of claudin 1 on cell proliferation, migration and apoptosis in human cervical squamous cell carcinoma
}

\author{
ZHEN SHEN $^{1 *}$, WEIGUO SONG ${ }^{2 *}$, LILI QIAN $^{1}$, JING ZHU $^{1}$, YUEBO LI $^{1}$, MIN LI $^{1}$, \\ TIANJIAO ZHANG ${ }^{1}$, WEIDONG ZHAO ${ }^{1}$, YING ZHOU ${ }^{1}$ and XINGSHENG YANG ${ }^{3}$
}

\author{
${ }^{1}$ Department of Obstetrics and Gynecology, The First Affiliated Hospital of the University of Science and \\ Technology of China, Anhui Provincial Hospital, Hefei, Anhui 230001; ${ }^{2}$ Department of Gynecology and Obstetrics, \\ The Second Affiliated Hospital of Anhui Medical University, Hefei, Anhui 230601; ${ }^{3}$ Department of Gynecology \\ and Obstetrics, Qilu Hospital of Shandong University, Jinan, Shandong 250012, P.R. China
}

Received May 6, 2020; Accepted October 5, 2020

DOI: $10.3892 / o r .2020 .7889$

\begin{abstract}
Claudin 1 is a member of the claudin protein family that serves an important role in tight junctions. Increased or decreased expression levels of claudin 1 are found in several diseases, including breast cancer and viral infections. However, the function of claudin 1 in cervical cancer remains controversial. The aim of the present study was to investigate the biological functions of claudin 1 in different human cervical cancer cell lines. First, SiHa and ME-180 cells with stable claudin 1 overexpression or knockdown were established using lentiviral transduction, and the mRNA and protein levels were measured via reverse transcription-quantitative PCR and western blot analysis. Subsequently, cell proliferation, colony formation and migration experiments were performed in vitro using standard protocols, demonstrating that claudin 1 was able to inhibit cell proliferation and migration in both $\mathrm{SiHa}$ and ME-180 cells. Furthermore, cell cycle and apoptosis were detected via flow cytometry and western blotting, and the results revealed that claudin 1 inhibited cell cycle progression and promoted apoptosis. To further verify whether claudin 1 was involved in tumor growth in vivo, xenograft tumors were established in athymic mice via injecting $\mathrm{SiHa}$ cells overexpressing claudin 1, which was found to decrease tumor growth in vivo. Furthermore, the association between claudin 1 expression and prognosis was analyzed in different types of cancer in The Cancer Genome Atlas. Overall, the findings of the present study revealed that claudin 1 may serve an antitumor role in cervical squamous cell carcinoma and may be of value as a potential therapeutic target.
\end{abstract}

Correspondence to: Professor Xingsheng Yang, Department of Gynecology and Obstetrics, Qilu Hospital of Shandong University, 107 Wenhuaxi Road, Jinan, Shandong 250012, P.R. China

E-mail: xingshengyang@sdu.edu.cn

*Contributed equally

Key words: claudin 1, cell proliferation, migration, apoptosis

\section{Introduction}

Cervical cancer is the fourth most frequently diagnosed tumor and the fourth leading cause of cancer-associated mortality among women worldwide, with an estimated 570,000 cases and 311,000 deaths according to the 2018 Global Cancer Statistics (1-4). Persistent infection with high-risk human papillomaviruses (HPVs) is a well known major cause of $\sim 95 \%$ of cervical squamous intraepithelial lesions and invasive cervical cancer, and poses a major threat to the health of women (5-8). With the advent of high-quality screening programs for cervical cancer and precancerous lesions, such as liquid-based cytology, Papanicolaou smear test, HPV test and the relatively recent development and application of the HPV vaccine, the incidence rate of cervical cancer has exhibited a marked decline, particularly in developed countries (9). In some developing countries or remote areas, a large proportion of women are not screened or voluntarily vaccinated against $\mathrm{HPV}$, and therefore cervical cancer remains the leading cause of cancer-associated mortality among women in 43 less developed countries $(10,11)$. Despite improvements in surgical treatment, chemotherapy and radiotherapy in recent decades, the prognosis of patients with advanced cervical cancer remains poor (12). Therefore, it is urgent to investigate the possible pathogenic mechanism underlying the development of cervical cancer, and further research on novel therapeutic strategies is required.

The claudin family, which includes $\sim 18$ closely related transmembrane proteins, serves a key structural role in tight junctions (13-17). Tight junctions are a type of cell-to-cell adhesion molecules in epithelial or endothelial cells, preventing the lateral diffusion of integral membrane proteins between the lateral, basal and apical surfaces (18-21), thereby preserving the specialized functions of each surface. Additionally, tight junctions have been reported to be associated with cell proliferation $(22,23)$, migration (24) and differentiation in different types of cells, such as Madin-Darby Canine Kidney and lactating mammary epithelial cells (25).

Claudin 1 (CLDN1), which has four transmembrane domains with two extracellular loops, was the first member 
of the claudin family to be identified and named $(26,27)$. Increased or decreased expression levels of CLDN1 have been reported to damage the epithelial permeability barrier and disrupt cellular polarity, which results in decreased cell adhesion (28). For example, Ryu et al (26) observed that downregulation of CLDN1 may lead to atopic dermatitis through the ERK/STAT3 signaling pathway. Furthermore, increased or decreased expression levels of CLDN1 have been found to be associated with several types of tumor; for example, overexpression of CLDN1 has been observed in nasopharyngeal, ovarian and oral squamous cell cancer (29). A number of studies have revealed that CLDN1 upregulation may contribute to tumor progression in esophageal squamous cell carcinoma, colon cancer and gastric carcinoma (30-32), while in other types of cancer, such as lung adenocarcinoma, CLDN1 acts as a tumor suppressor by activating the expression of matrix metallopeptidase-2 and high CLDN1 expression is associated with an improved prognosis (33). In prostate adenocarcinoma, Sheehan et al (34) demonstrated that patients with loss of CLDN1 protein expression had a higher rate of disease recurrence. Therefore, CLDN1 serves distinct roles in different types of tissue and tumor (29,35-37). However, the role of CLDN1 in cervical cancer remains unclear. Several studies have reported that CLDN1 protein expression may promote the migration of cervical cancer cells and increase the risk of lymph node metastasis $(38,39)$. Another study investigated the role of CLDN1 and CLDN7 in HeLa cells and revealed that neither of them promoted tumorigenesis in cervical cancer, but rather decreased the migratory and invasive abilities of cells (40). Therefore, these different results may be partially attributed to the different cervical cancer cell subtypes.

The transcription factor p63 is a member of the p53 gene family that serves an important role in epidermal development and diseases (41). A previous study (42) has demonstrated that $\Delta \mathrm{Np} 63 \alpha$ is the most abundant isoform expressed in cervical cancer cells and exerts an antitumor effect. Further analyses, including chromatin immunoprecipitation sequencing (Chip-seq) and RNA sequencing (RNA-seq) results, demonstrated that $\Delta \mathrm{Np} 63 \alpha$ can directly regulate the expression levels of the target gene CLDN1 $(41,42)$.

The aim of the present study was to explore the effects of CLDN1 on the biological behavior of cervical squamous cell cancer cells, in order to determine whether CLDN1 may act as an anti-oncogene in cervical cancer, and whether it may represent a potential target for improving the effectiveness of diagnosis and treatment of cervical cancer.

\section{Materials and methods}

Cell lines. 293T cells and the cervical squamous cell carcinoma SiHa and ME-180 cell lines were purchased from the American Type Culture Collection and cultured under suitable conditions. 293 T and SiHa cells were cultured in DMEM (HyClone; Cytiva) supplemented with 10\% FBS (Biological Industries) and $1 \%$ penicillin/streptomycin at $37^{\circ} \mathrm{C}$ in humidified atmosphere containing $5 \% \mathrm{CO}_{2}$. ME-180 cells were cultured in McCoy's 5A medium (HyClone; Cytiva) supplemented with $10 \%$ FBS and $1 \%$ penicillin/streptomycin at $37^{\circ} \mathrm{C}$ in a humidified atmosphere containing $5 \% \mathrm{CO}_{2}$.
Overexpression of CLDN1 in SiHa cells. The specific PCR primers of CLDN1 were as follows: Forward, 5'-CTAGGC GCCGGAATTAGATCTGCCACCATGGCCAAC GCG GGGCTGCA-3' (restriction site, BglII) and reverse, 5'-GCG GAATTCGTTAACCTCGAGTCACACGTAGTC TTTCCC GC-3' (restriction site, XhoI). The full-length human CLDN1 was obtained by reverse transcription-quantitative PCR (RT-qPCR) analysis and cloned into the pMIGR1 plasmid (Wuhan Miaoling Biological Technology Co., Ltd.), which was named as the pMIGR1-CLDN1 plasmid. The plasmid was confirmed by sequencing analysis and the US National Center for Biotechnology Information blasting (data not shown). Subsequently, $3 \mu \mathrm{g}$ plasmids combined with $3 \mu \mathrm{g}$ packaging vectors pCL-10A1 (Wuhan Miaoling Biological Technology Co., Ltd.) were transfected into $293 \mathrm{~T}$ cells using Lipofectamine ${ }^{\circledR} 2000$ transfection reagent (Invitrogen; Thermo Fisher Scientific, Inc.; pMIGR1 plasmid: pCL-10A1=1:1). After $10 \mathrm{~h}$ at $37^{\circ} \mathrm{C}$, the cell medium was changed, and after a further $48 \mathrm{~h}$ of incubation at $37^{\circ} \mathrm{C}$, the viral supernatant of $293 \mathrm{~T}$ cells was collected by centrifugation $(12,000 \mathrm{x}$ g for $10 \mathrm{~min})$ at room temperature. Subsequently, $700 \mu 1$ virus supernatant mixed with $300 \mu \mathrm{l}$ normal culture medium were used to infect SiHa cells (multiplicity of infection $\sim 10^{6} \mathrm{PFU} / \mathrm{ml}$ ) in a 12-well plate for 36-48 h. Subsequently, SiHa/CLDN1 stable cell lines were obtained by selection with $400 \mu \mathrm{g} / \mathrm{ml} \mathrm{G}-418$ (Beijing Solarbio Science \& Technology Co., Ltd.) for 2-3 weeks (32), after which the untransfected and unstable SiHa cells would be dead, while the control cells ( $\mathrm{SiHa} / \mathrm{con}$ ) and SiHa/CLDN1 stable cells would survive. Stably transfected cells were identified using western blotting and RT-qPCR analysis.

Overexpression of CLDN1 in ME-180/shp63. Firstly, ME-180/shp63 cells were constructed successfully. The library of shRNAs used for producing viral-packaged interfering RNAs for target genes was obtained from Sigma-Aldrich (Merck KGaA). The p63-short hairpin (sh)RNA plasmid contained a shRNA sequence targeting p63 (5'-ACAGAC CCTTTGTAGCGTG-3'; target at position 3,648 to 3,666). The lentiviral vectors pLKO.1 or p63-shRNA were used for plasmid construction and transfected into 293T cells simultaneously with helper plasmids (VSVG, $2 \mu \mathrm{g}$; GAG, $2 \mu \mathrm{g}$; Rev, $22 \mu \mathrm{g}$; shRNA, $1 \mu \mathrm{g}$ ) using Lipofectamine 2000. After $10 \mathrm{~h}$, the cell medium was changed and after $48 \mathrm{~h}$, the viral supernatant of $293 \mathrm{~T}$ cells was collected by centrifugation $(12,000 \mathrm{x} \mathrm{g}$ for $10 \mathrm{~min})$ at room temperature to remove the dead cells. Subsequently, $700 \mu 1$ virus supernatant mixed with $300 \mu 1$ normal culture medium were used to infect ME-180 cells (multiplicity of infection was $\sim 10^{6} \mathrm{PFU} / \mathrm{ml}$ ) at $37^{\circ} \mathrm{C}$ for 36-48 h. ME-180/shp63 stable cell lines were obtained by selection with $2 \mu \mathrm{g} / \mathrm{ml}$ puromycin (Merck; KGaA) for 2 weeks. Secondly, CLDN1 overexpression was induced in ME-180/shp63 cells. To establish the double transfected cell lines in which p63 was knocked down but CLDN1 was overexpressed, the pLKO.1 vectors were modified by replacing the puromycin-resistant cassette with the G418-resistant cassette. The experimental process was performed as aforementioned for SiHa cells, except that ME-180/shp63-CLDN1 stable cell lines were obtained by selection with $400 \mu \mathrm{g} / \mathrm{ml}$ G-418 (Beijing Solarbio Science \& Technology Co., Ltd.) for 2-3 weeks. 
Knockdown of CLDN1 by shRNA. First, the SiHa/p63 cells overexpressing p63 were constructed. The specific PCR primers of p63 were as follows: Forward, 5'- GAAGATCTG CCACCATGTTGTACCTGGA-3' (restriction site, $B g l \mathrm{II}$ ) and reverse,5'-CCGCTCGAGTCACTCCCCCTCCTCTTT GA-3' (restriction site, XhoI). The full-length human p63 was obtained by RT-qPCR and cloned into the pMIGR1 plasmid (Wuhan Miaoling Biological Technology Co., Ltd.), which was named as the pMIGR1-p63 plasmid. The next experimental steps were as aforementioned for the overexpression of CLDN1 in SiHa cells. Stably transfected cells were identified using western blotting and RT-qPCR analysis.

The CLDN1-shRNA plasmid containing the target shRNA sequences (5'-GCATCGTTATTAAGCCCTTAT-3' at position 1,490 to 1,510 ) and the shRNA control plasmid pLKO.1 (Shaanxi YouBio Technology Co., Ltd.) were constructed by the School of Life Sciences, University of Science and Technology of China (Hefei, China). Lentiviral vectors pLKO.1 or CLDN1-shRNA were used for plasmid construction and transduced into 293T cells simultaneously with helper plasmids ( $1 \mu \mathrm{g}$ lentiviral plasmid; $6 \mu \mathrm{g}$ packaging vector) using Lipofectamine 2000. After $10 \mathrm{~h}$, the cell medium was changed and after a further $48 \mathrm{~h}$, the viral supernatant of $293 \mathrm{~T}$ cells was collected by centrifugation $(12,000 \mathrm{x}$ g for $10 \mathrm{~min}$ at room temperature) to remove the dead cells. Subsequently, $700 \mu \mathrm{l}$ virus supernatant mixed with $300 \mu \mathrm{l}$ normal culture medium was used to infect $\mathrm{SiHa} / \mathrm{p} 63$ cells (multiplicity of infection was $\sim 10^{6} \mathrm{PFU} / \mathrm{ml}$ ) at $37^{\circ} \mathrm{C}$ for $36-48 \mathrm{~h}$. The supernatants were replaced with fresh medium with $2.0 \mu \mathrm{g} / \mathrm{ml}$ puromycin. $\mathrm{SiHa} / \mathrm{p} 63$-shCLDN1 stable cell lines were obtained by selection with $2 \mu \mathrm{g} / \mathrm{ml}$ puromycin for 2-3 weeks and were detected via RT-qPCR analysis and western blotting.

Cell proliferation in vitro. A total of $6 \times 10^{4}$ cells in $100 \mu \mathrm{l}$ of their respective culture medium, including $\mathrm{SiHa} /$ con and $\mathrm{SiHa} / \mathrm{CLDN} 1, \mathrm{SiHa} / \mathrm{p} 63$-pLKO and $\mathrm{SiHa}$ /p63-shCLDN1, ME-180/shp63-con and ME-180/shp63-CLDN1, were seeded into 16-well plates (ACEA Bioscience, Inc.) and measured using the xCELLigence Real-Time Cell Analysis measuring instrument (Roche Diagnostics). Each type of cell was added to $>3$ wells and the steps were strictly followed according to the manufacturer's protocol. After $100 \mathrm{~h}$, the cell proliferation plot was acquired using the xCELLigence system (Roche Diagnostics).

Colony formation assay. A total of 100 cells/well from each cell line (SiHa/con and $\mathrm{SiHa} / \mathrm{CLDN} 1$, $\mathrm{SiHa} / \mathrm{p} 63$-pLKO and SiHa/p63-shCLDN1, ME-180/shp63-con and ME-180/shp63-CLDN1) were seeded into 6-well plates separately. SiHa/con, SiHa/CLDN1, SiHa/p63-pLKO and $\mathrm{SiHa} / \mathrm{p} 63$-shCLDN1 cells were cultured in DMEM supplemented with $10 \%$ FBS, whereas ME-180/shp63-con and ME-180/shp63-CLDN1 cells were cultured in McCoy's $5 \mathrm{~A}$ supplemented with $10 \%$ FBS. Experiments in each cell line were run in triplicate at $37^{\circ} \mathrm{C}$ in a humidified atmosphere of $5 \% \mathrm{CO}_{2}$. After 2 weeks, the colonies ( $\geq 10$ cells) were observed under a light microscope (Olympus Corporation; magnification, $x 100$ ). The cells were washed twice with PBS and stained with $0.5 \%$ crystal violet for $1 \mathrm{~min}$ at room temperature (Beijing Solarbio Science \& Technology Co.,Ltd.).
The quantitation of the colony formation assays was described using histograms. The results represent mean values of two duplicate experiments, and error bars indicate standard deviation.

Wound healing assays. For wound healing assays, $4 \times 10^{5}$ cells/well from each cell line ( $\mathrm{SiHa} / \mathrm{con}$ and $\mathrm{SiHa} / \mathrm{CLDN} 1$, SiHa/p63-pLKO and SiHa/p63-shCLDN1, ME-180/shp63-con and ME-180/shp63-CLDN1) were seeded in 6-well plates. After the cells were adhered, the cell monolayers were scratched using a pipette tip and washed gently with PBS to remove cell debris. Subsequently, all cells were cultured in DMEM or McCoy's 5A medium supplemented with $1 \%$ FBS. In this experiment, the aim was to investigate the migratory ability in the two cell lines ( $\mathrm{SiHa} /$ con and $\mathrm{SiHa} / \mathrm{CLDN} 1$ ). Culturing cells in normal culture medium (with 10\% FBS) can make it difficult to distinguish whether cell migration or cell proliferation are promoting wound healing (43). Therefore, DMEM or McCoy's 5A medium supplemented with 1\% FBS were used to culture cells. Cell migration was assessed by measuring the movement of the cells into the scratch in the well. Images were captured under a light microscope (Olympus Corporation; magnification, x100) at 24 and $48 \mathrm{~h}$ to quantify the wound closure rate. Each experiment was performed in triplicate.

Cell cycle analysis. $\mathrm{SiHa} / \mathrm{con}$ and $\mathrm{SiHa} / \mathrm{CLDN} 1$, SiHa/p63-pLKO and SiHa/p63-shCLDN1, ME-180/shp63-con and ME-180/shp63-CLDN1 cells were plated in 6-well plates at a density of $2 \times 10^{5}$ cells/well and cultured at $37^{\circ} \mathrm{C}$ overnight. Subsequently, all cells were starved in serum-free DMEM for $48 \mathrm{~h}$, after which they were cultured with $10 \%$ FBS and DMEM for another $24 \mathrm{~h}$ at $37^{\circ} \mathrm{C}$. The cells in each group were fixed with $70 \%$ ethanol overnight at $4^{\circ} \mathrm{C}$ and washed twice with PBS. Subsequently, the cells were re-suspended with $400 \mu \mathrm{l}$ binding buffer and stained with $20 \mu \mathrm{l}$ PI (Sigma-Aldrich; Merck KGaA) for $20 \mathrm{~min}$ at room temperature in the dark. The cell cycle distribution was analyzed immediately using a FACSCalibur flow cytometer (Becton, Dickinson and Company). The percentage of cells at each phase of the cell cycle was calculated using FlowJo 2.0 (FlowJo LLC). All assays were performed in triplicate and repeated three times.

Flow cytometric cell death assay. $\mathrm{SiHa} / \mathrm{con}$ and $\mathrm{SiHa} / \mathrm{CLDN} 1$ cells were plated at a density of $5 \times 10^{5}$ cells/well in 6-well plates and cultured for $48 \mathrm{~h}$ at $37^{\circ} \mathrm{C}$. Total cells were collected and washed twice in binding buffer and stained with allophycocyanin-labeled Annexin-V (BioLegend, Inc.) software in the dark for $20 \mathrm{~min}$ at room temperature. Subsequently, the cells were stained with PI in the dark for $\sim 5 \mathrm{~min}$ at room temperature. The cells were analyzed using a CytoFLEX flow cytometer (Beckman Coulter, Inc.) and then the data was analyzed for percentage of viable, early apoptotic and late apoptotic cells using FlowJo 2.0 software (FlowJo LLC). All assays were performed in triplicate and repeated three times.

Tumorigenicity in mice. A total of 10 female BALB/c (nu/nu) mice (Shanghai SLAC Laboratory Animal Co., Ltd.; age, 4 weeks; weight, $11.5 \mathrm{~g}$ ) were kept in 12-h light/dark cycle at a 
temperature of $23^{\circ} \mathrm{C}$ under specific pathogen-free atmosphere with 40-60\% humidity and free access to sufficient food and water. After 1 week, $100 \mu 1$ serum-free DMEM containing $6 \times 10^{6} \mathrm{SiHa} /$ con or $\mathrm{SiHa} / \mathrm{CLDN} 1$ cells $(\mathrm{n}=5 \mathrm{mice} / \mathrm{group}$ ) were injected into the mouse right thigh. The growth of solid tumors in mice was measured by Vernier calipers every 3 days for up to 35 days. The tumor volume (V) was calculated as follows: $\mathrm{V}=0.5 \mathrm{x}$ length $\mathrm{x}$ width $^{2}$. Subsequently, all the mice were sacrificed by cervical dislocation at the end of the experiment and the tumors were completely removed for analysis. The animal experiment was approved by the Animal Care and Use Committee of the University of Science and Technology of China.

$R T-q P C R$ analysis. Total RNA was isolated from $\mathrm{SiHa}$ or ME-180 cells using TRIzol ${ }^{\circledR}$ reagent (Invitrogen; Thermo Fisher Scientific, Inc.) according to the manufacturer's protocol. RT was performed using PrimeScript ${ }^{\mathrm{TM}}$ RT Reagent kit (Invitrogen; Thermo Fisher Scientific, Inc.) following the manufacturer's protocol. RT-qPCR was performed in a final volume of $20 \mu \mathrm{l}$ containing $1 \mu \mathrm{l}$ cDNA, $1 \mu \mathrm{l}$ primers $(10 \mu \mathrm{M})$ and $10 \mu \mathrm{l}$ SYBR Green PCR Master Mix (Roche Diagnostics) in an ABI-7300 real-time PCR machine. The following thermocycling conditions were used: $95^{\circ} \mathrm{C}$ for $5 \mathrm{~min}, 40$ cycles at $94^{\circ} \mathrm{C}$ for $10 \mathrm{sec}$ and $60^{\circ} \mathrm{C}$ for $31 \mathrm{sec}$, followed by the dissociation stage at $95^{\circ} \mathrm{C}$ for $15 \mathrm{sec}, 60^{\circ} \mathrm{C}$ for $60 \mathrm{sec}$ and $95^{\circ} \mathrm{C}$ for $15 \mathrm{sec}$. The following primers (5'-3') were used: GAPDH forward, CTTCATTGACCTCAACTACATGG and reverse, CTCGCTCCTGGAAGATGGTGAT; and CLDN1 forward, TCTGGGAGGTGCCCTACTTT and reverse, CTGGAAGGT GCAGGTTTTGG. GAPDH was used as a control. Relative expression of the mRNA was calculated using the $2^{-\Delta \Delta C q}$ method (44) and normalized to GAPDH.

Western blotting. Cell samples were collected and washed with PBS. Proteins were extracted using RIPA lysis buffer (Beijing Solarbio Science \& Technology Co., Ltd.). Protein concentration was quantified using a BCA Protein Assay kit (Thermo Fisher Scientific, Inc.). Proteins ( 30 $\mu \mathrm{g} /$ lane) were separated via $10 \%$ SDS-PAGE and transferred onto PVDF membranes (EMD Millipore). The membranes were blocked in $5 \%$ bovine serum albumin (Beijing Solarbio Science \& Technology Co., Ltd.; cat. no. SW3015) for $45 \mathrm{~min}$ at room temperature and then probed with the indicated primary antibodies at $4^{\circ} \mathrm{C}$ overnight. The following primary antibodies were used: p63 (dilution 1:1,000; Cell Signaling Technology, Inc.; cat. no. 39692), CLDN1 (dilution 1:1,000; Cell Signaling Technology, Inc.; cat. no. 13255), PARP-1 (dilution 1:500; Santa Cruz Biotechnology Inc.; cat. no. sc56197), cleaved PARP (dilution 1:500; Cell Signaling Technology, Inc.; cat. no. 9548), caspase-3 (dilution 1:500; Cell Signaling Technology, Inc.; cat. no. 9662), caspase-7 (dilution 1:500; Cell Signaling Technology, Inc.; cat. no. 9492), caspase-9 (dilution 1:1,000; Cell Signaling Technology, Inc.; cat. no. 9502), cleaved caspase-9 (dilution 1:500; Cell Signaling Technology, Inc.; cat. no. 20750), GAPDH (dilution 1:2,000; ProteinTech Group, Inc.; cat. no. 10494-1-AP) and $\beta$-actin (dilution 1:2,000; ProteinTech Group, Inc.; cat. no. 20536-1-AP). The secondary antibodies were HRP-conjugated goat anti-mouse IgG (dilution 1:3,000;
ProteinTech Group, Inc.; cat. no. SA00001-1) or goat anti-rabbit IgG (dilution 1:3,000; ProteinTech Group, Inc.; cat. no. SA00001-2). The appropriate secondary antibodies were applied for $1 \mathrm{~h}$ at room temperature. The protein levels were detected via enhanced chemiluminescence substrate (Advansta, Inc.; cat. no. K-12045-D50.) and exposed to chemiluminescent film.

Statistical analysis. Data from all the experiments were presented as the mean \pm standard deviation using GraphPad Prism 6 (GraphPad Software, Inc.), and were replicated at least three times. Student's two-tailed unpaired t-tests were used to assess the statistical significance of the differences between groups. Survival curves were plotted using the Kaplan Meier-plotter and analyzed using the log-rank test (http://kmplot.com/). $\mathrm{P}<0.05$ was considered to indicate a statistically significant difference.

\section{Results}

CLDN1 acts as an anti-oncogene in SiHa cells. In order to study the effect of CLDN1 on cell proliferation, SiHa/CLDN1 cell lines overexpressing CLDN1 were constructed, and the control cell line was named $\mathrm{SiHa} / \mathrm{con}$. The western blot and RT-qPCR analyses demonstrated that CLDN1 expression at both the mRNA and protein level in SiHa/CLDN1 cells was higher compared with that in $\mathrm{SiHa} /$ con cells; therefore, stable cell lines with CLDN1 overexpression were obtained (Fig. 1A and B). SiHa/con and SiHa/CLDN1 cells were seeded into an ACEA 16-well plate and cell proliferation was measured. It was observed that overexpression of CLDN1 significantly suppressed cell proliferation compared with control cells (Fig. 1C). Furthermore, the number of cell colonies formed by $\mathrm{SiHa} / \mathrm{CLDN} 1$ cells was significantly decreased compared with that formed by $\mathrm{SiHa} /$ con cells (Fig. 1D and E). In the wound healing assays, after $48 \mathrm{~h}$ of culture, the wound healing rate of SiHa/CLDN1 cells was significantly lower compared with that in the SiHa/con cell group (Fig. 1F). Overall, the present results indicated that CLDN1 inhibited SiHa cervical cancer cell proliferation and migration.

CLDN1 suppresses the proliferation of ME-180/shp63 cells. Since the expression of CLDN1 is downregulated in the ME-180/shp63 cell line(41), in order to further study the function of CLDN1, a ME-180/shp63 cell line with CLDN1 overexpression was established and named ME-180/shp63-CLDN1, whereas the control cell line was named ME-180/shp63-con. The mRNA and protein levels of CLDN1 in the two cell lines was then detected via western blotting and RT-qPCR analysis. The results demonstrated that the expression levels of CLDN1 in ME-180/shp63-CLDN1 cells were higher compared with those in ME-180/shp63-con cells at both the mRNA and protein levels (Fig. 2A and B). Subsequently, the proliferation of the two cell lines was examined, and it was observed that overexpression of CLDN1 in ME-180/shp63 cells significantly suppressed their proliferation compared with control cells (Fig. 2C). The number of colonies formed by ME-180/shp63-CLDN1 cells was significantly decreased compared with that formed by control cells (Fig. 2D and E). The wound healing assay demonstrated that the wound 

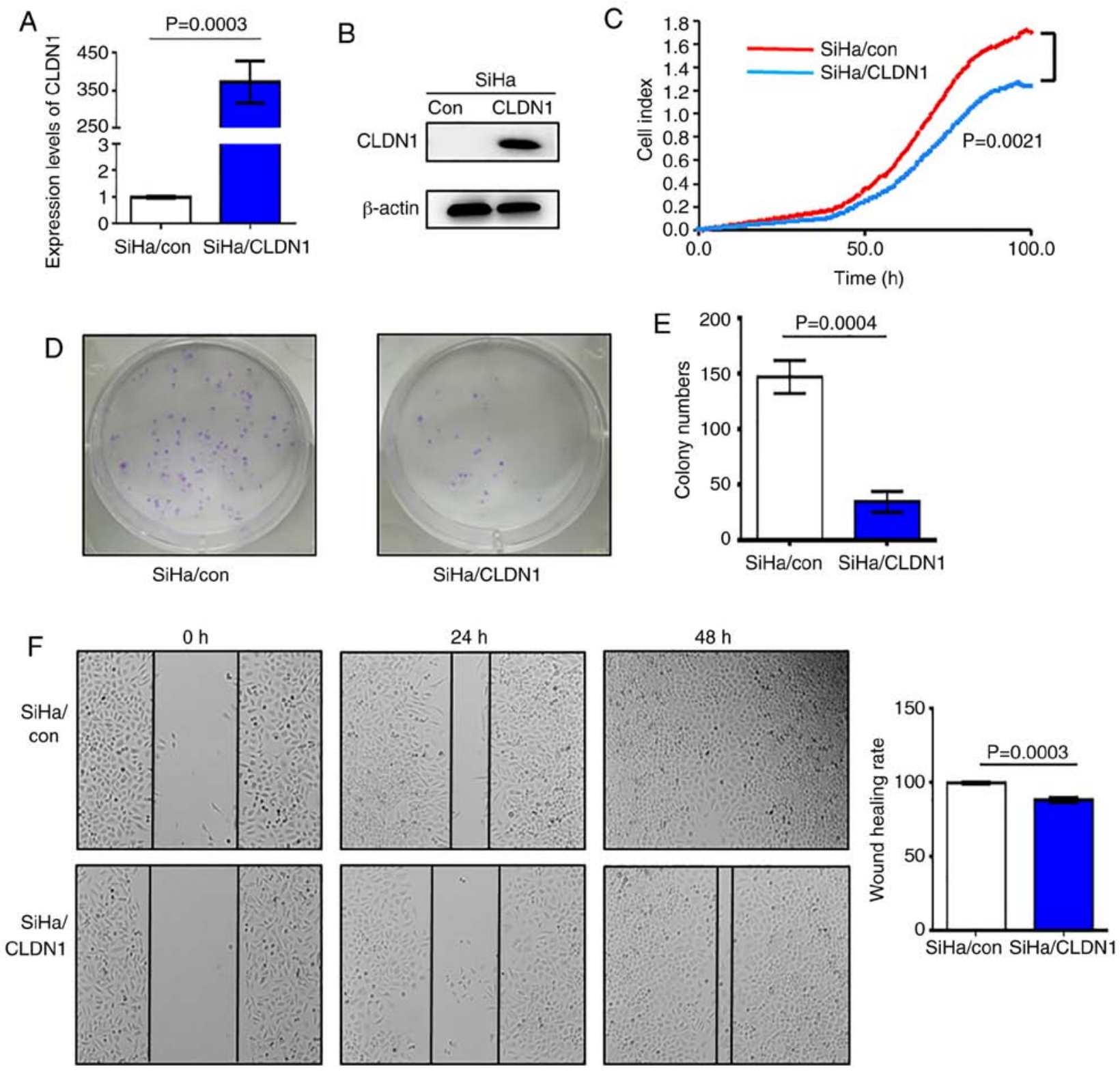

Figure 1. CLDN1 inhibits the proliferation of SiHa cells. (A) Reverse transcription-quantitative PCR analysis of CLDN1 expression in the SiHa/con and $\mathrm{SiHa} / \mathrm{CLDN} 1$ cell groups ( $\mathrm{P}=0.0003)$. (B) Protein expression levels of CLDN1 in the $\mathrm{SiHa} /$ con and $\mathrm{SiHa} / \mathrm{CLDN} 1$ cell groups were detected by western blotting. (C) Cell proliferation was detected by Real-Time Cell Analysis in SiHa/con and SiHa/CLDN1 cells ( $\mathrm{P}=0.0021)$. (D and E) Colony formation assay revealed that CLDN1 overexpression inhibited cell proliferation $(\mathrm{P}=0.0004)$. (F) Wound healing rate of $\mathrm{SiHa} /$ con cells was higher compared with that of $\mathrm{SiHa} / \mathrm{CLDN} 1$ cells (magnification, $\mathrm{x} 100 ; \mathrm{P}=0.0003$ ). Data are presented as the mean $\pm \mathrm{SD}$ and analyzed using a two-tailed unpaired Student's t-test from three independent experiments. CLDN1, claudin 1; con, control

healing rate of ME-180/shp63-CLDN1 cells was significantly lower compared with that of the control cell group (Fig. 2F). Therefore, CLDN1 was also found to act as an anti-oncogene in ME-180 cells.

Knockdown of CLDN1 promotes the proliferation of SiHa/p63 cells. Overexpression of CLDN1 exerted antitumor effects on the SiHa and ME-180/shp63 cell lines. It was next determined whether CLDN1 knockdown by shRNA could promote cervical cancer progression. The $\mathrm{SiHa} / \mathrm{p} 63$-shCLDN1 cell line was constructed and the control cell line was named SiHa/p63-pLKO. The western blot and RT-qPCR analyses revealed that CLDN1 expression was knocked down at both the mRNA and protein levels in $\mathrm{SiHa} / \mathrm{p} 63$-shCLDN1 cells compared with the control cells (Fig. 3A and B). The SiHa/p63-shCLDN1 cells exhibited increased proliferative and colony-forming abilities compared with the SiHa/p63-pLKO cells (Fig. 3C-E). Additionally, knockdown of CLDN1 significantly increased cell migration compared with that of control cells (Fig. 3F).

CLDN1 participates in cell cycle regulation. In order to study the cell cycle distribution of the 3 groups of cell lines (SiHa/con and SiHa/CLDN1, ME-180/shp63-con and ME-180/shp63-CLDN1, and SiHa/p63-pLKO and $\mathrm{SiHa} / \mathrm{p} 63$-shCLDN1), the cell cycle was examined by flow cytometry. The results demonstrated that the proportion 

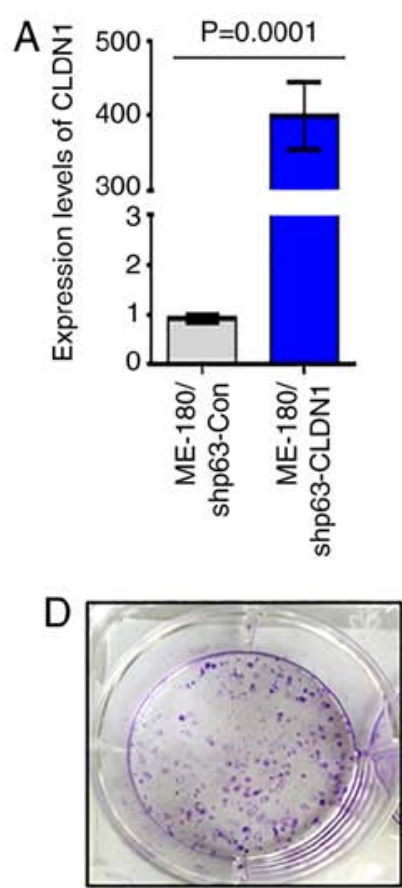

ME-180/

shp63-Con

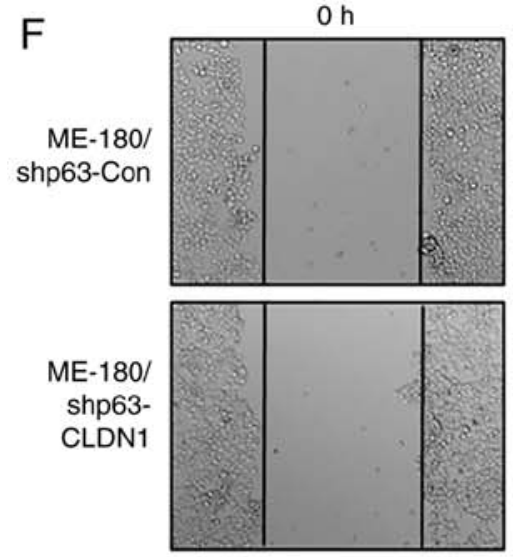

B

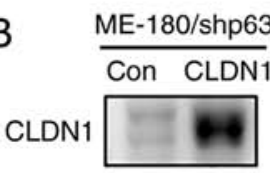

$\beta$-actin
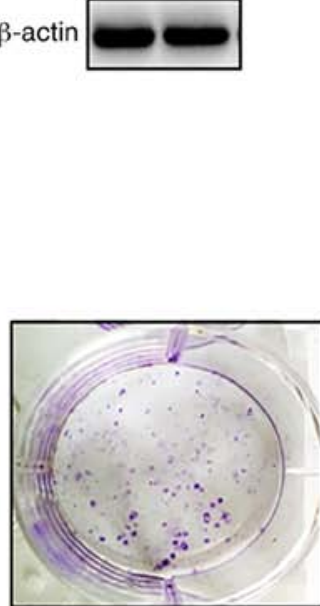

ME-180/ shp63-CLDN1
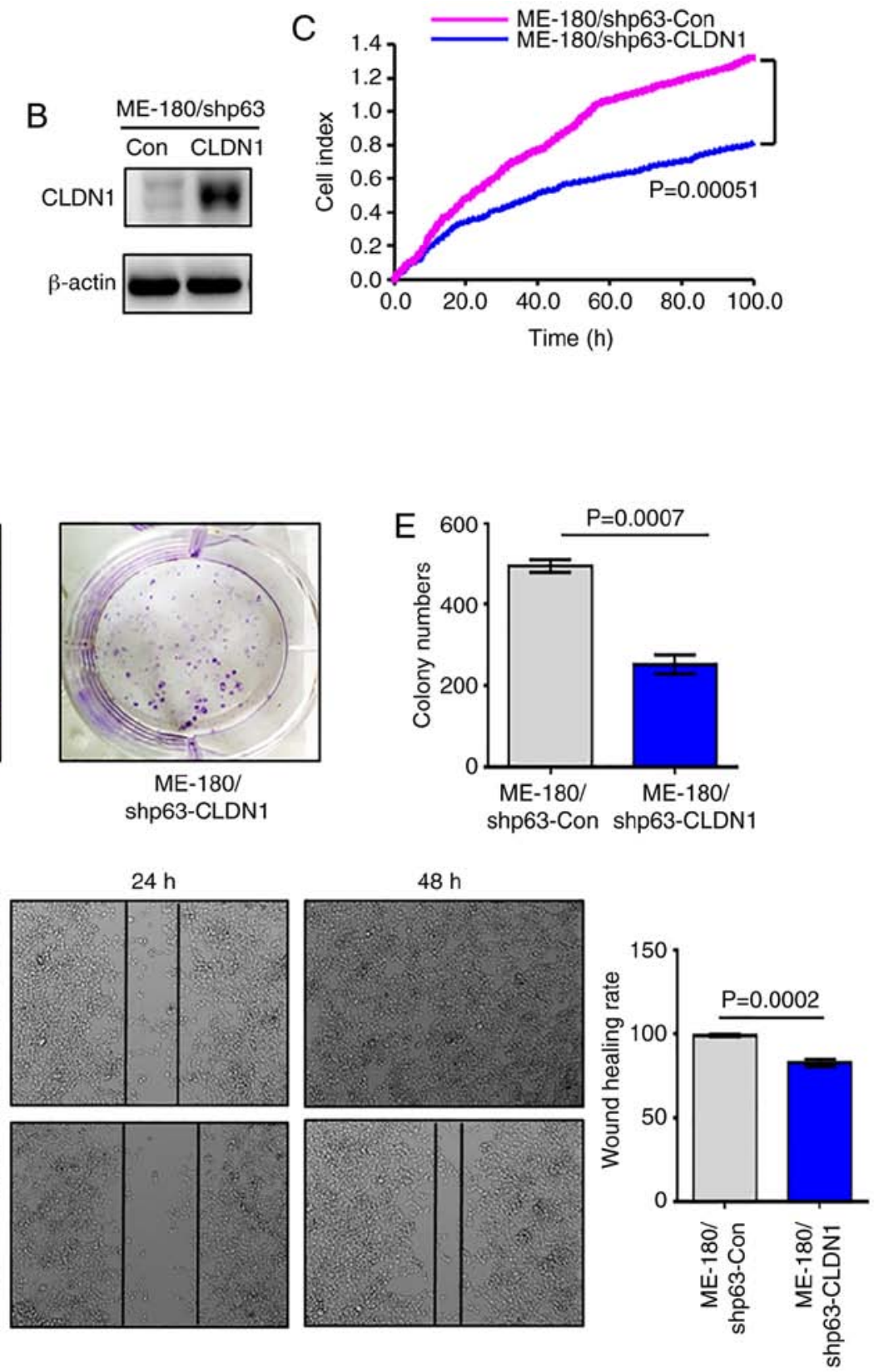

Figure 2. CLDN1 inhibits the proliferation of ME-180 cells. (A) Reverse transcription-quantitative PCR (P=0.0001) and (B) western blot analysis of the expression levels of CLDN1 in ME-180/shp63-Con and ME-180/shp63-CLDN1 cells. (C) Cell proliferation of ME-180/shp63-COn and ME-180/shp63-CLDN1 was detected by Real-Time Cell Analysis ( $\mathrm{P}=0.00051)$. (D and E) Colony formation assay revealed that CLDN1 overexpression inhibited the cell proliferation of ME-180/shp63 cells. $(\mathrm{P}=0.0007)$. (F) Wound healing rate of ME-180/shp63-Con was higher compared with that of ME-180/shp63-CLDN1 cells (magnification, $\mathrm{x} 100 ; \mathrm{P}=0.0002$ ). Data are presented as the mean $\pm \mathrm{SD}$ in triplicates and analyzed using a two-tailed unpaired Student's t-test from three independent experiments. CLDN1, claudin 1; Con, control; sh, short hairpin.

of $\mathrm{SiHa} /$ con and $\mathrm{SiHa} / \mathrm{CLDN} 1$ cells in the $\mathrm{G}_{1}$ phase was $67.42 \pm 1.26$ and $81.54 \pm 1.35 \%$, respectively (Fig. $4 \mathrm{~A}$ and $\mathrm{B}$ ). The cell cycle was primarily arrested at the $\mathrm{G}_{1}$ phase in the $\mathrm{SiHa} / \mathrm{CLDN} 1$ cell group compared with the $\mathrm{SiHa} / \mathrm{con}$ cell group. Similarly, changes in the cell cycle of ME-180 cells were detected, and it was observed that the proportion of cells in the $\mathrm{G}_{1}$ phase in the ME-180/shp63-con and ME-180/shp63-CLDN1 cell groups was $92.12 \pm 1.36$ and $98.24 \pm 1.13 \%$, respectively (Fig. 4C and D). Similarly, when CLDN1 was knocked down in SiHa/p63 cells, the proportion of $\mathrm{SiHa} / \mathrm{p} 63$-pLKO and $\mathrm{SiHa} / \mathrm{p} 63$-shCLDN1 cells in the $\mathrm{G}_{1}$ phase was $86.22 \pm 1.14$ and $75.21 \pm 1.25 \%$, respectively
(Fig. 4E and F). The current results demonstrated that CLDN1 affected cell cycle distribution and arrested cells in the $\mathrm{G}_{1}$ phase.

CLDN1 inhibits tumor growth in vivo. Based on the in vitro results, the present study next sought to verify the role of CLDN1 in cell proliferation in vivo. A tumor-bearing mouse model was established by transplanting $\mathrm{SiHa} / \mathrm{con}$ and $\mathrm{SiHa} / \mathrm{CLDN} 1$ cells. The tumor sizes are shown in Fig. 5A and B. The expression levels of CLDN1 in the two tumor groups were confirmed by western blot and RT-qPCR analyses (Fig. 5C and D). Tumor size and weight in the $\mathrm{SiHa} / \mathrm{con}$ group were significantly 


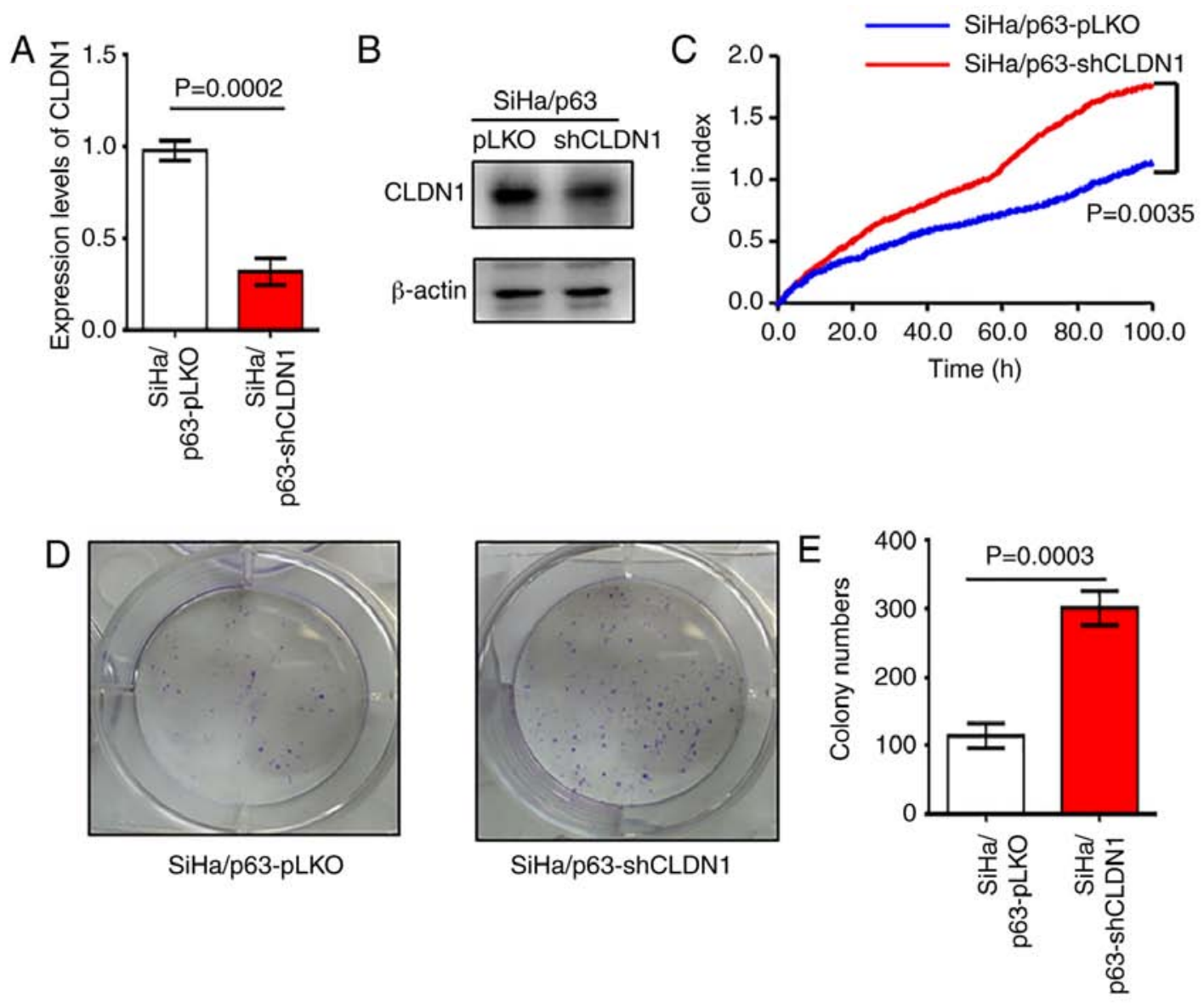

$\mathrm{F}$

$\mathrm{Oh}$

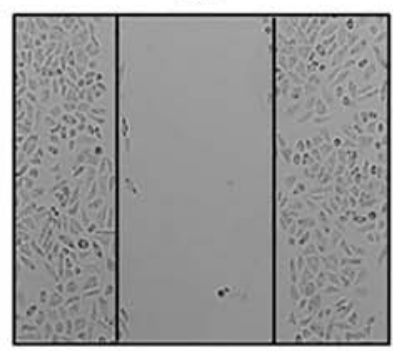

$\mathrm{SiHa}$ p63-shCLDN1

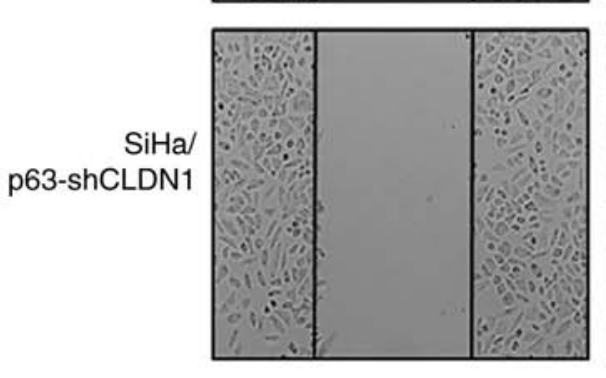

$24 \mathrm{~h}$
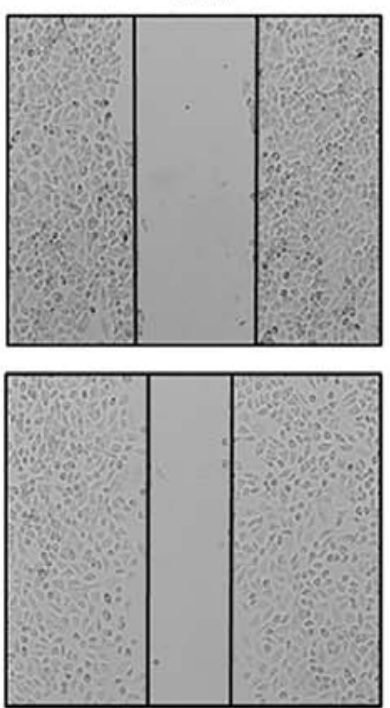
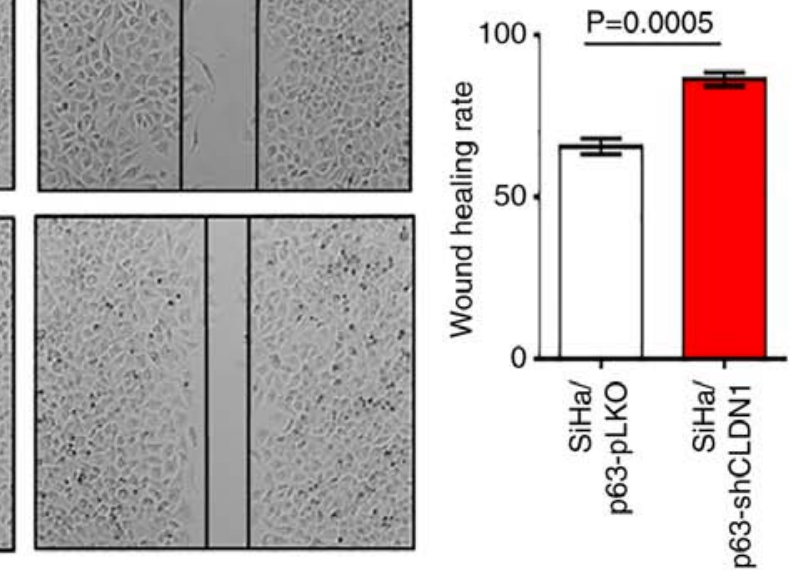

Figure 3. CLDN1 knockdown promotes cell proliferation in SiHa/p63 cell lines. (A) Reverse transcription-quantitative PCR and (B) western blot analysis of the expression levels of CLDN1 in SiHa/p63-pLKO and SiHa/p63-shCLDN1 cells ( $\mathrm{P}=0.0002)$. (C) Cell proliferation of SiHa/p63-pLKO and SiHa/p63-shCLDN1 cells was detected by Real-Time Cell Analysis assay ( $\mathrm{P}=0.0035$ ). (D and E) Colony formation assay between SiHa/p63-pLKO and SiHa/p63-shCLDN cell lines revealed that $\mathrm{SiHa} / \mathrm{p} 63$-shCLDN1 promoted the proliferation of cervical cancer cells $(\mathrm{P}=0.0003)$. (F) Wound healing rate of $\mathrm{SiHa} / \mathrm{p} 63-\mathrm{pLKO}$ cells was lower than that of $\mathrm{SiHa} / \mathrm{p} 63$-shCLDN1 cells $(\mathrm{P}=0.0005$; magnification, $\mathrm{x} 100)$. Data are presented as the mean $\pm \mathrm{SD}$ in triplicates and analyzed using a two-tailed unpaired Student's t-test from three independent experiments. CLDN1, claudin 1; sh, short hairpin.

higher compared with those in the SiHa/CLDN1 group (Fig. 3E and F). As expected, CLDN1 overexpression in SiHa cells inhibited tumor growth in vivo compared with control tumors.
CLDN1 promotes apoptosis in cervical cancer cells. To investigate the role of CLDN1 in cell apoptosis, the expression levels of apoptosis-associated proteins were detected in the $\mathrm{SiHa} / \mathrm{CLDN} 1$ and $\mathrm{SiHa} /$ con cell groups by western blotting. 

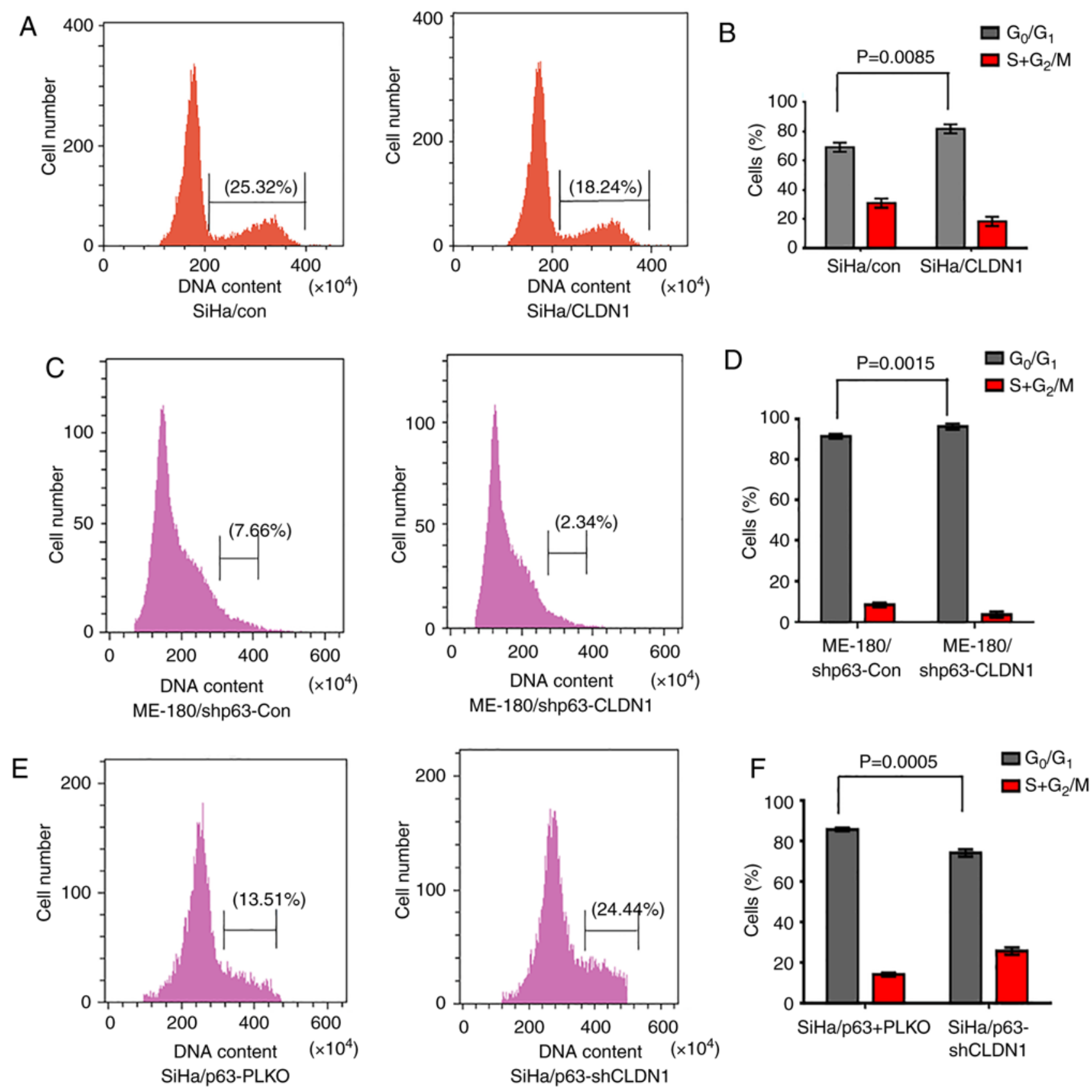

Figure 4. CLDN1 participates in cell cycle regulation. Overexpression of CLDN1 decreased the proportion of cells in $\mathrm{S}$ phase and increased the proportion of cells in $\mathrm{G}_{1}$ phase in (A and B) SiHa $(\mathrm{P}=0.0085)$ and $(\mathrm{C}$ and $\mathrm{D}) \mathrm{ME}-180 / \mathrm{shp63}(\mathrm{P}=0.0015)$ cells, as detected by flow cytometry with PI staining. (E and F) CLDN1 knockdown in SiHa/p63 cells increased the proportion of cells in S phase and decreased the proportion of cells in $\mathrm{G}_{1}$ phase $(\mathrm{P}=0.0005)$. Data are expressed as the mean \pm SD in triplicates and analyzed using a two-tailed unpaired Student's t-test from three independent experiments. CLDN1, claudin 1; Con, control; sh, short hairpin.

The results indicated that the expression levels of PARP, cleaved-PARP, caspase-3, 7 and cleaved 9 in SiHa/CLDN1 cells were markedly increased compared with those in $\mathrm{SiHa} / \mathrm{con}$ cells (Fig. 6A). Additionally, flow cytometric cell death assay was performed. As shown in Fig. 6B and C, cell apoptosis was significantly increased in $\mathrm{SiHa}$ cells with CLDN1 overexpression ( $\mathrm{P}=0.0027)$.

Association of CLDN1 expression with the prognosis in other types of human tumor. To further study the effect of CLDN1 on patient prognosis, CLDN1 expression in other types of tumor was analyzed using the Kaplan-Meier plotter in the pan-cancer RNA-Seq mRNA database. Sources for the databases include Gene Expression Omnibus, the European Genome-phenome Archive and The Cancer Genome Atlas (http://kmplot.com/analysis), and there are a total of 21 types of cancer that can be analyzed, including bladder carcinoma, ovarian cancer and head and neck squamous cell carcinoma. In cervical cancer, the upper quartile survival of the high CLDN1 expression cohort was 68.4 months, while in the low CLDN1 expression cohort it was 27.63 months $(\mathrm{P}=0.0046$; Fig. 7A), which was consistent with our previous study (41). Additionally, CLDN1 expression was found to be associated with prognosis in seven other types of tumor, as shown in 

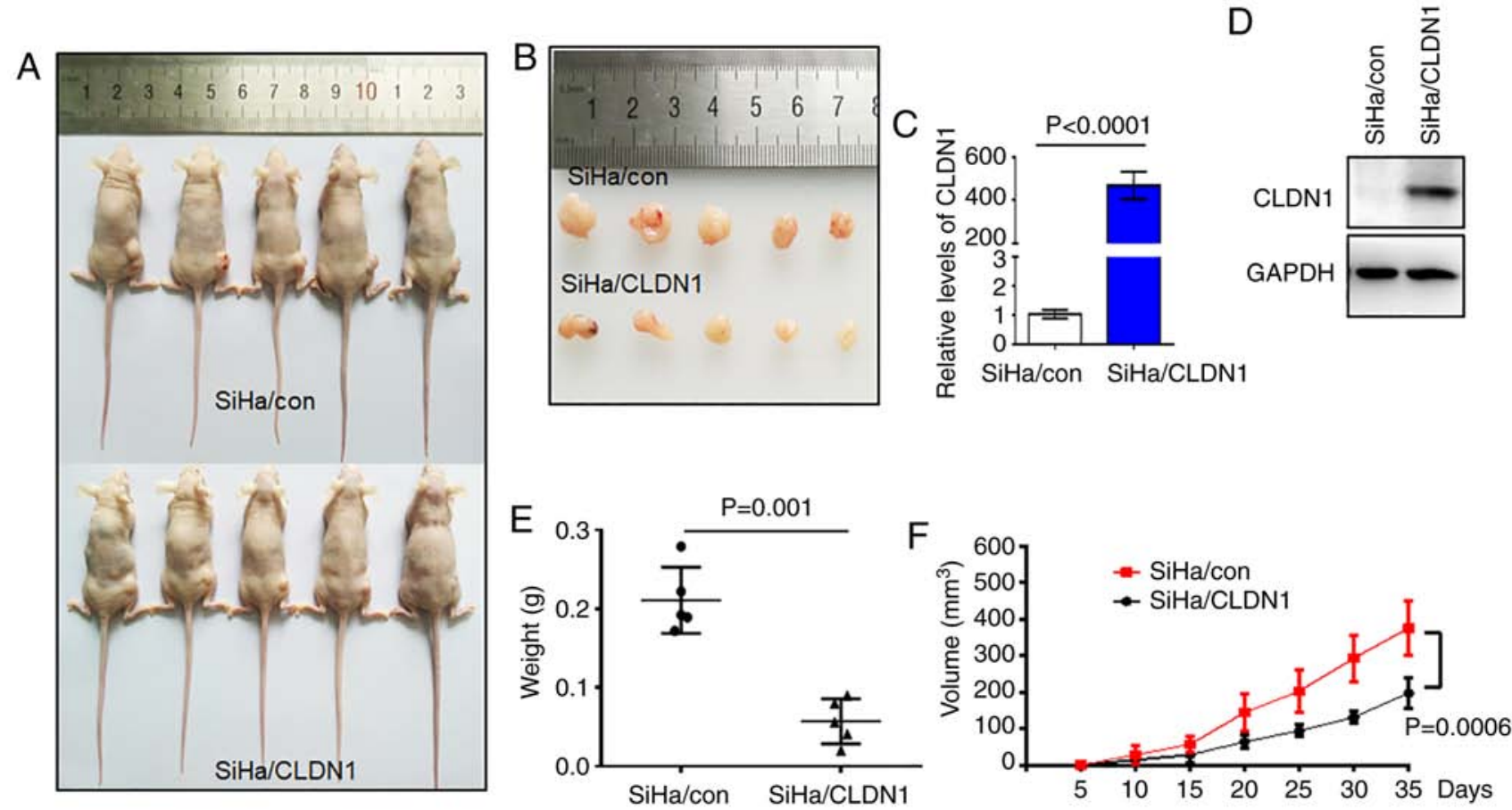

Figure 5. CLDN1 overexpression inhibits tumor growth in vivo. (A and B) Images of the xenograft tumors in the two groups after tumor cell injection for up to 35 days. Relative expression levels of CLDN1 in tumor tissues were detected by (C) reverse transcription-quantitative $\mathrm{PCR}(\mathrm{P}<0.0001)$ and $(\mathrm{D})$ western blot analysis. (E) Tumor weight distribution in the two groups $(\mathrm{P}=0.001)$. (F) Tumor growth curves in the two groups ( $\mathrm{P}=0.0006)$. Data are expressed as the mean \pm SD in triplicates and analyzed using a two-tailed unpaired Student's $t$-test from three independent experiments. CLDN1, claudin 1; con, control.

A

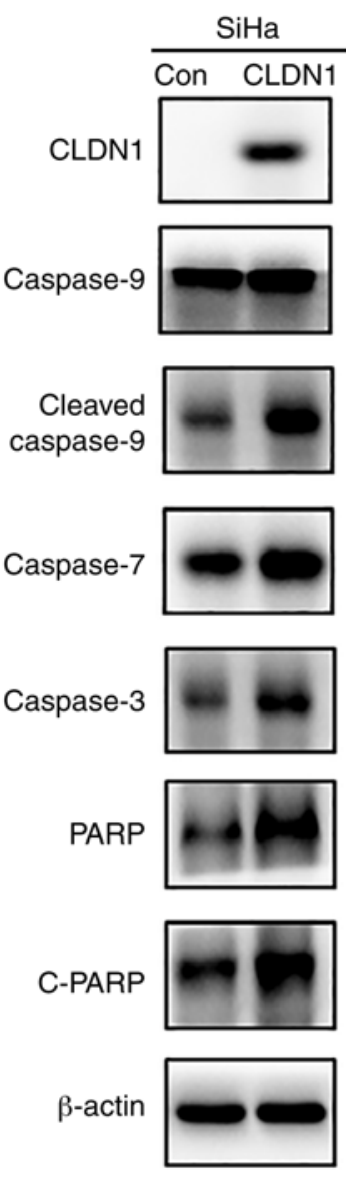

$B \bar{\alpha}$
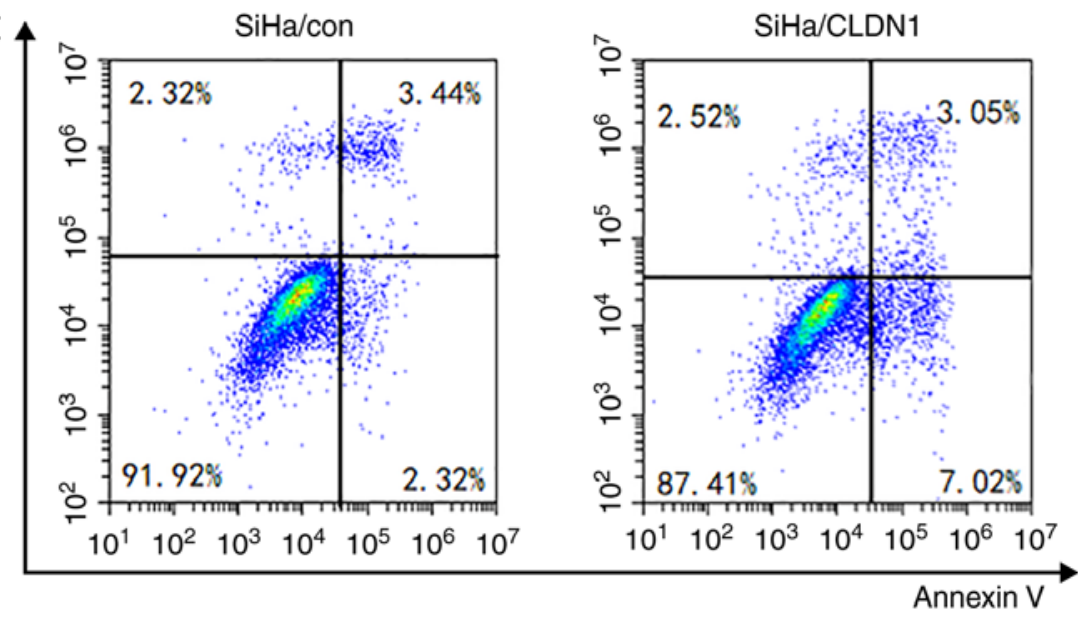

C

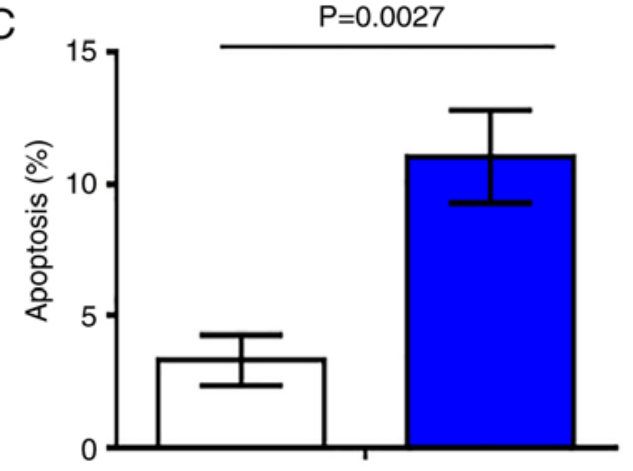

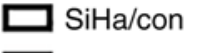

$\mathrm{SiHa/CLDN1}$

Figure 6. CLDN1 promotes apoptosis of cervical cancer cells. (A) Overexpression of CLDN1 increased the expression levels of apoptosis-associated proteins as detected by western blotting. (B and C) Overexpression of CLDN1 induced apoptosis of SiHa cells as detected by flow cytometric cell death assay ( $\mathrm{P}=0.0027)$. CLDN1, claudin 1; con, control; PARP, poly (ADP-ribose) polymerase; c-, cleaved. 

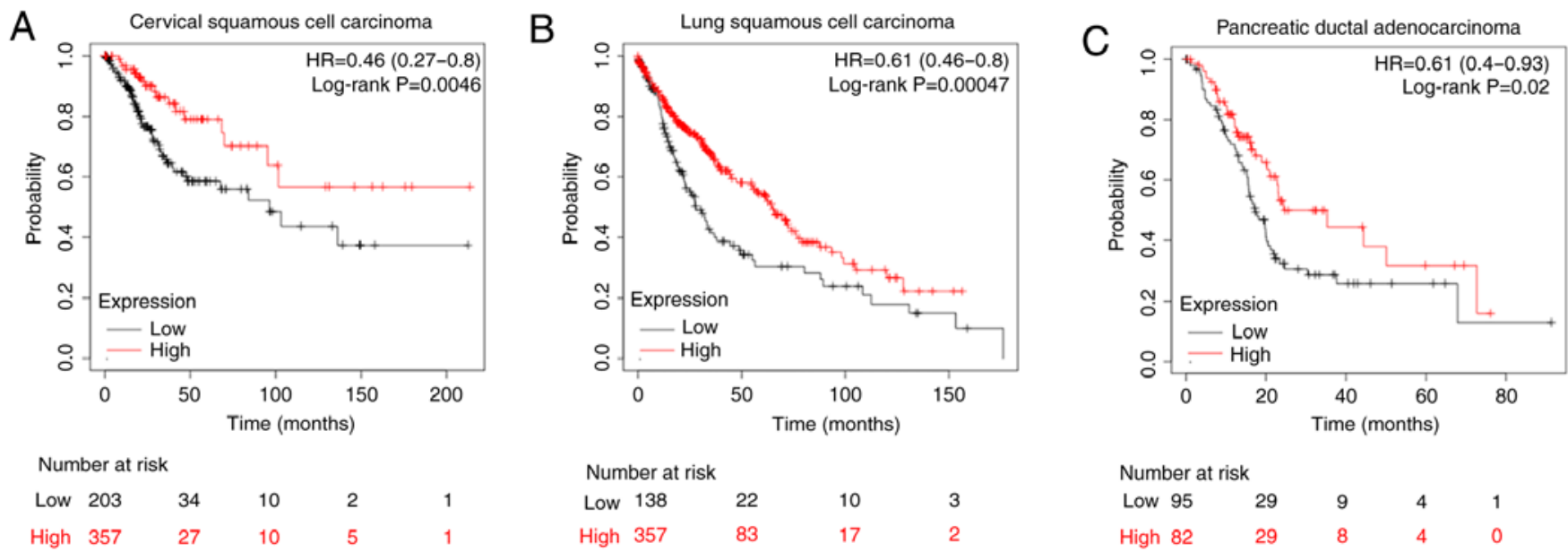

$\begin{array}{llll}\text { Number at risk } & & & \\ \text { Low } 138 & 22 & 10 & 3 \\ \text { High } 357 & 83 & 17 & 2\end{array}$
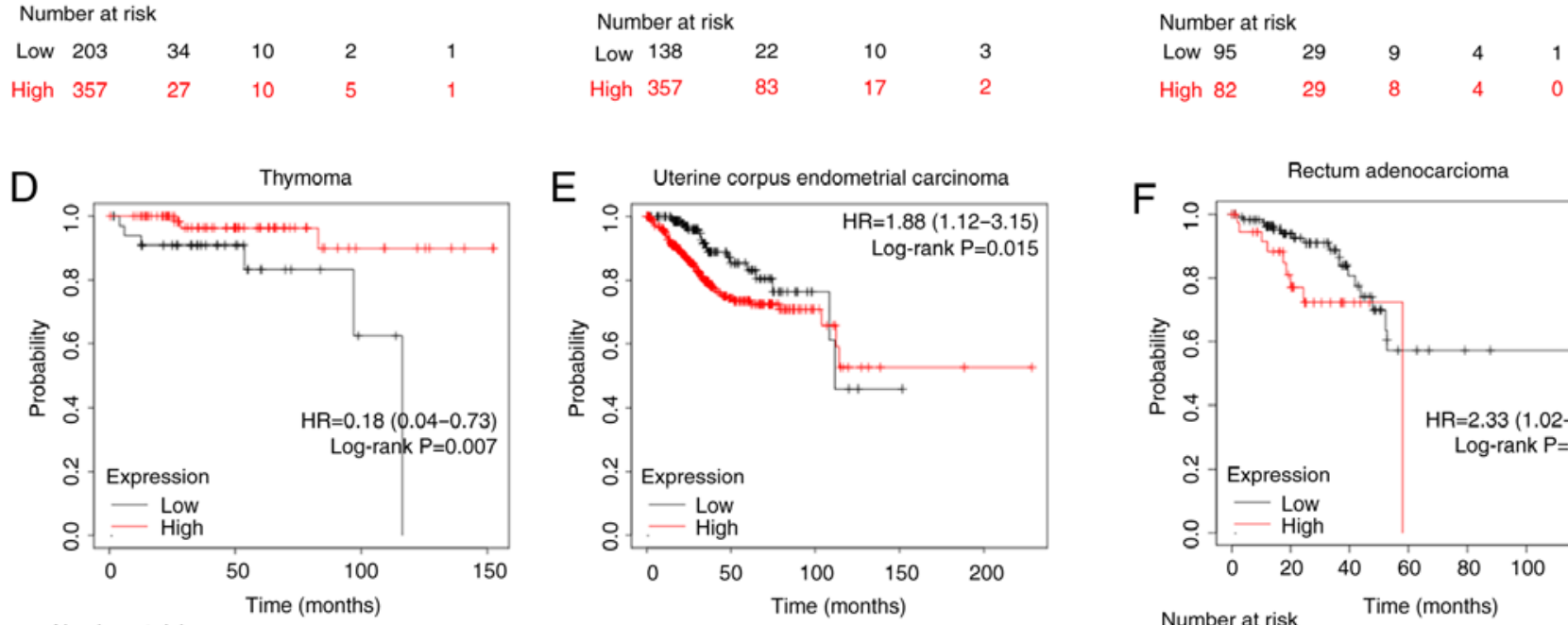

$\begin{array}{llll}\text { Number at risk } & & & \\ \text { Low 35 } & 15 & 2 & 0 \\ \text { High } 83 & 35 & 9 & 2\end{array}$

\begin{tabular}{lllll}
\multicolumn{2}{l}{ Number at risk } & & & \\
Low 95 & 29 & 9 & 4 & 1 \\
High 82 & 29 & 8 & 4 & 0
\end{tabular}
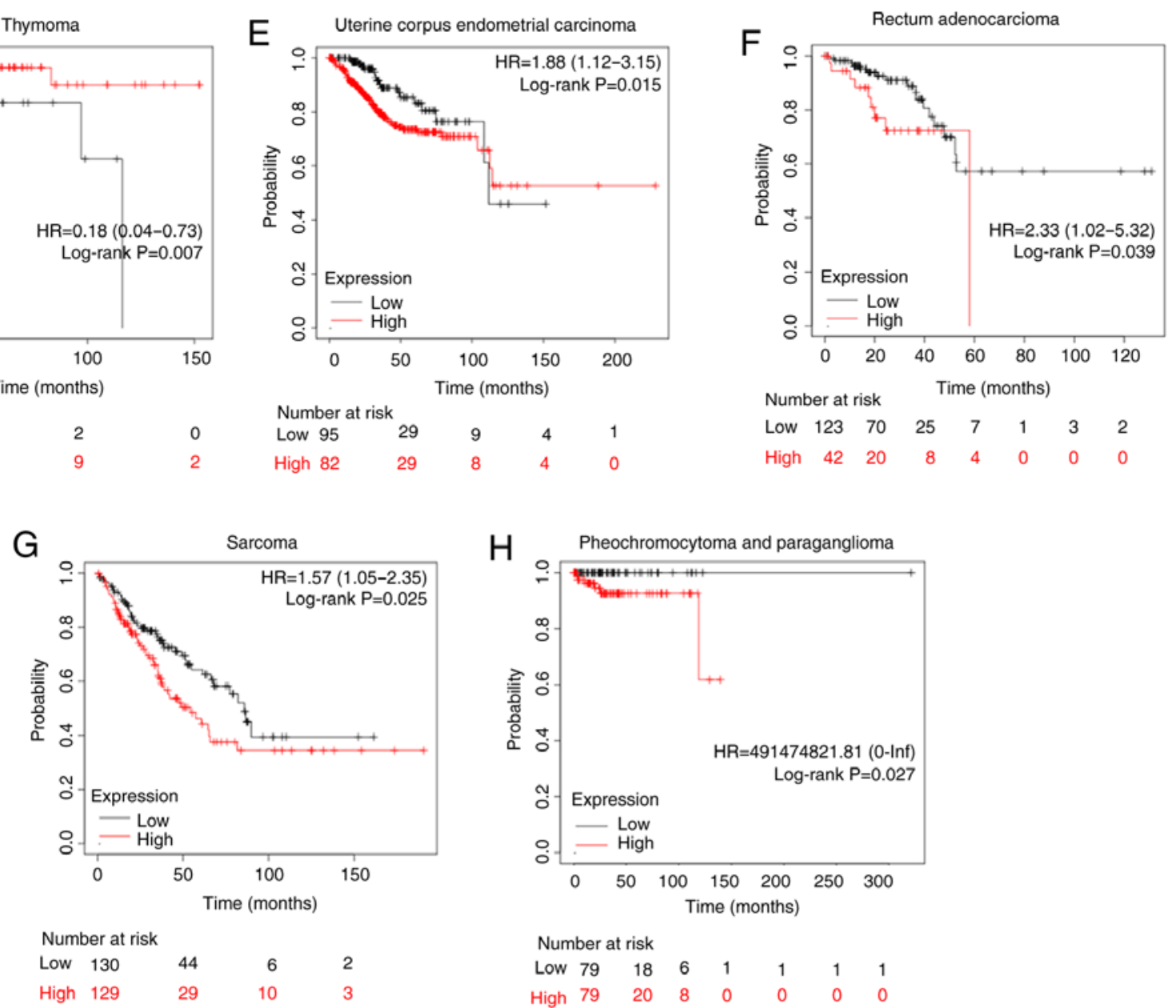

Figure 7. Survival analysis of CLDN1 in various types of cancer. High CLDN1 expression in (A) cervical squamous cell carcinoma, (B) lung squamous cell carcinoma, (C) pancreatic ductal adenocarcinoma and (D) thymoma predicted an improved overall survival compared with low CLDN1 expression, as analyzed using The Cancer Genome Atlas database. In (E) uterine corpus endometrial carcinoma, (F) rectal adenocarcinoma, $(\mathrm{G})$ sarcoma and (H) pheochromocytoma and paraganglioma, high CLDN1 expression predicted a poor overall survival. CLDN1, claudin 1; HR, hazard ratio.

Fig. 7. High CLDN1 expression was directly associated with an improved overall survival in patients with lung squamous cell carcinoma, pancreatic ductal adenocarcinoma and thymoma (Fig. 7B-D). However, high CLDN1 expression was directly associated with a poor prognosis in patients with uterine corpus endometrial carcinoma, rectal adenocarcinoma, pheochromocytoma and paraganglioma, and sarcoma
(Fig. 7E-H). Therefore, the role of CLDN1 differed across different types of tumor.

\section{Discussion}

CLDN1 is a member of the claudins, which is a family of $17-27 \mathrm{kDa}$ integral membrane tight junction proteins that 
determine the size of the molecules that pass through the paracellular space in epithelial and endothelial tissues (36). There are limited data available on the molecular interactions among the claudins. The expression levels of CLDN1 have been investigated in several types of cancer and different expression levels of CLDN1 have been associated with tumorigenesis in different types of cancer (45). Downregulation of CLDN1 leads to characteristic morphological alterations of tight junction fine structure (46). It has been demonstrated that loss of CLDN1 expression stimulates tumor progression and invasion in certain types of cancer, such as melanocytic neoplasia (47), while in esophageal squamous cell carcinoma, increased CLDN1 expression was associated with tumor progression (48-50). For example, Youssefian et al (51) reported that a novel mutation in CLDN1 was identified in neonatal ichthyosis and was associated with sclerosing cholangitis, referred to as the NISCH syndrome, which may be used for molecular confirmation of the diagnosis in some of these patients. Furthermore, polymorphisms in the CLDN1 gene were associated with the age of patients and differentiation of triple-negative breast cancer (TNBC), but there was no association between polymorphisms in CLDN1 and survival of patients with TNBC (52). However, the function of CLDN1 may vary even in the same type of cancer, such as breast cancer (52). Loss of CLDN1 expression in patients with breast cancer was associated with tumor invasion and metastasis by Tokés et al (53), whereas CLDN1 contributed to migration of luminal-like MCF7 human breast cancer cells (54).

In our previous study, the results demonstrated that the transcription factor $\Delta \mathrm{Np} 63 \alpha$ serves an antitumor role in cervical squamous cell cancer (41). CLDN1 was found to be a direct target of $\Delta \mathrm{Np} 63 \alpha$ by Chip-seq and RNA-Seq, which was verified by western blot and RT-qPCR analysis. Additionally, the expression levels of $\Delta \mathrm{Np} 63 \alpha$ and CLDN1 were significantly decreased in cervical tumor samples compared with in adjacent normal tissues (41). Thus, it was inferred that p63 may inhibit the progression of cervical cancer by regulating CLDN1, but its definitive function in cervical cancer remains elusive. Therefore, the current study further investigated the function of CLDN1 in cervical cancer cells. In the present study, rescue experiments were performed by knocking down CLDN1 in SiHa/p63 cells and overexpressing CLDN1 in ME-180/shp63 cells, and the results demonstrated that CLDN1 inhibited the proliferation and migration of cervical cancer cells. Additionally, the in vivo experiments in tumor-bearing mice revealed that the overexpression of CLDN1 inhibited cell proliferation. Anticancer cytotoxic activity was mostly mediated via arresting the cell cycle at the $\mathrm{G}_{0} / \mathrm{G}_{1}$ phases, thereby inhibiting cell proliferation, and eventually leading to apoptosis. Based on the present findings, CLDN1 appeared to inhibit cervical cancer growth by inducing cancer cell apoptosis. The possible underlying mechanism may involve multiple factors or signaling pathways, including Smad, $\beta$-catenin, the Snail family and the ERK1/2, PI3K/AKT and AMPK signaling pathways $(55,56)$.

In summary, the present study revealed that CLDN1 may act as a tumor suppressor gene in cervical cancer. However, the underlying mechanisms requires further investigation in future studies. The current findings provide a strong basis for the further exploration of CLDN1 as a new therapeutic target for cervical cancer.

\section{Acknowledgements}

Not applicable.

\section{Funding}

The present study was supported by the National Key R\&D Program of China (grant no. 2018YFC1003900), the National Natural Science Foundation of China (grant nos. 81902632, 81872110 and 81272881) and the Fundamental Research Funds for the Central Universities (grant no. WK9110000104).

\section{Availability of data and materials}

All data generated or analyzed during this study are included in this published article.

\section{Authors' contributions}

ZS and WS performed the experiments and analyzed the data. LQ constructed the stable overexpression cell lines and wrote part of the manuscript. YL and JZ prepared the figures. ML performed the statistical analyses. TZ and WZ assisted with the experiments and data interpretation. YZ performed most of the revision experiments. XY designed the majority of the experiments and wrote the manuscript. All authors read and approved the final manuscript.

\section{Ethics approval and consent to participate}

All experiments involving animals were performed in accordance with the guidelines of the Animal Care and Use Committee of the University of Science \& Technology of China using a peer-reviewed protocol (approval no. USTCACUC1801017).

\section{Patient consent for publication}

Not applicable.

\section{Competing interests}

The authors declare that they have no competing interests.

\section{References}

1. Bray F, Ferlay J, Soerjomataram I, Siegel RL, Torre LA and Jemal A: Global cancer statistics 2018: GLOBOCAN estimates of incidence and mortality worldwide for 36 cancers in 185 countries. CA Cancer J Clin 68: 394-424, 2018.

2. Underwood SM, Ramsay-Johnson E, Browne L, Caines N, Dean A, Duval S, Ivalis R, Lawrence ND, Lewis N, Mulkanen M, et al: What women in the United States Virgin Islands still want and need to know about HPV, cervical cancer, and condom use. J Natl Black Nurses Assoc 21: 25-32, 2010.

3. Malagón T, Kulasingam S, Mayrand MH, Ogilvie G, Smith L, Bouchard C, Gotlieb W and Franco EL: Age at last screening and remaining lifetime risk of cervical cancer in older, unvaccinated, HPV-negative women: A modelling study. Lancet Oncol 19: $1569-1578,2018$ 
4. Hoevel T, Macek R, Swisshelm K and Kubbies M: Reexpression of the TJ protein CLDN1 induces apoptosis in breast tumor spheroids. Int J Cancer 108: 374-383, 2004.

5. Bjurberg M, Beskow C, Kannisto P and Lindahl G: Cervical cancer is a clinical challenge. Lakartidningen 112, 2015 (In Swedish).

6. Hu Z and Ma D: The precision prevention and therapy of HPV-related cervical cancer: New concepts and clinical implications. Cancer Med 7: 5217-5236, 2018.

7. Fang J, Zhang $\mathrm{H}$ and Jin S: Epigenetics and cervical cancer: From pathogenesis to therapy. Tumour Biol 35: 5083-5093, 2014.

8. Goodman A: HPV testing as a screen for cervical cancer BMJ 350: h2372, 2015.

9. Chrysostomou AC, Stylianou DC, Constantinidou A and Kostrikis LG: Cervical cancer screening programs in Europe: The transition towards HPV vaccination and population-based HPV testing. Viruses 10: 729, 2018.

10. Vu M, Yu J, Awolude OA and Chuang L: Cervical cancer worldwide. Curr Probl Cancer 42: 457-465, 2018.

11. Wuerthner BA and Avila-Wallace M: Cervical cancer: Screening, management, and prevention. Nurse Pract 41: 18-23, 2016.

12. Mountzios G, Soultati A, Pectasides D, Pectasides E, Dimopoulos MA and Papadimitriou CA: Developments in the systemic treatment of metastatic cervical cancer. Cancer Treat Rev 39: 430-443, 2013.

13. Zihni C, Mills C, Matter K and Balda MS: Tight junctions: From simple barriers to multifunctional molecular gates. Nat Rev Mol Cell Biol 17: 564-580, 2016.

14. Tsukita S, Tanaka H and Tamura A: The claudins: From tight junctions to biological systems. Trends Biochem Sci 44: 141-152, 2019.

15. Tsukita S, Furuse M and Itoh M: Multifunctional strands in tight junctions. Nat Rev Mol Cell Biol 2: 285-293, 2001.

16. Suzuki T: Regulation of intestinal epithelial permeability by tight junctions. Cell Mol Life Sci 70: 631-659, 2013.

17. Sawada N: Tight junction-related human diseases. Pathol Int 63 $1-12,2013$

18. Campbell HK, Maiers JL and DeMali KA: Interplay between tight junctions \& adherens junctions. Exp Cell Res 358: 39-44, 2017.

19. Amarnath S and Agarwala S: Cell-cycle-dependent TGF $\beta$-BMP antagonism regulates neural tube closure by modulating tight junctions. J Cell Sci 130: 119-131, 2017.

20. Wang X, Adegoke EO, Ma M, Huang F, Zhang H, Adeniran SO, Zheng P and Zhang G: Influence of Wilms' tumor suppressor gene WT1 on bovine Sertoli cells polarity and tight junctions via non-canonical WNT signaling pathway. Theriogenology 138 : 84-93, 2019.

21. Ruch TR and Engel JN: Targeting the mucosal barrier: How pathogens modulate the cellular polarity network. Cold Spring Harb Perspect Biol 9: a027953, 2017.

22. Li X, Ahmad US, Huang Y, Uttagomol J, Rehman A, Zhou K, Warnes G, McArthur S, Parkinson EK and Wan H: Desmoglein-3 acts as a pro-survival protein by suppressing reactive oxygen species and doming whilst augmenting the tight junctions in MDCK cells. Mech Ageing Dev 184: 111174, 2019.

23. Tsugami $Y$, Matsunaga $K$, Suzuki $T$, Nishimura $T$ and Kobayashi K: Phytoestrogens weaken the blood-milk barrier in lactating mammary epithelial cells by affecting tight junctions and cell viability. J Agric Food Chem 65: 11118-11124, 2017.

24. De Pascalis C and Etienne-Manneville S: Single and collective cell migration: The mechanics of adhesions. Mol Biol Cell 28 1833-1846, 2017.

25. Calder MD, Edwards NA, Betts DH and Watson AJ: Treatment with AICAR inhibits blastocyst development, trophectoderm differentiation and tight junction formation and function in mice. Mol Hum Reprod 23: 771-785, 2017.

26. Ryu WI, Lee H, Bae HC, Jeon J, Ryu HJ, Kim J, Kim JH, Son JW, Kim J, Imai Y, et al: IL-33 down-regulates CLDN1 expression through the ERK/STAT3 pathway in keratinocytes. J Dermatol Sci 90: 313-322, 2018.

27. Baktash Y, Madhav A, Coller KE and Randall G: Single particle imaging of polarized hepatoma organoids upon hepatitis $\mathrm{C}$ virus infection reveals an ordered and sequential entry process. Cell Host Microbe 23: 382-394.e5, 2018.

28. Liu H, Jiang F, Jia X, Lan J, Guo H, Li E, Yan A and Wang Y: Cycling hypoxia affects cell invasion and proliferation through direct regulation of claudin 1/claudin7 expression, and indirect regulation of P18 through claudin7. Oncotarget 8: 10298-10311, 2017.
29. Bhat AA, Syed N, Therachiyil L, Nisar S, Hashem S, Macha MA, Yadav SK, Krishnankutty R, Muralitharan S, Al-Naemi H, et al: Claudin-1, a double-edged sword in cancer. Int J Mol Sci 21: 569, 2020.

30. Dehghan Esmatabadi MJ, Farhangi B, Safari Z, Kazerooni H, Shirzad H, Zolghadr F and Sadeghizadeh M: Dendrosomal curcumin inhibits metastatic potential of human SW480 colon cancer cells through Down-regulation of Claudin1, Zeb1 and Hef1-1 gene expression. Asian Pac J Cancer Prev 16: 2473-2481, 2015.

31. Eftang LL, Esbensen Y, Tannæs TM, Blom GP, Bukholm IR and Bukholm G: Up-regulation of CLDN1 in gastric cancer is correlated with reduced survival. BMC Cancer 13: 586, 2013.

32. Wu J, Gao F, Xu T, Li J, Hu Z, Wang C, Long Y, He X, Deng X, Ren $\mathrm{D}$, et al: CLDN1 induces autophagy to promote proliferation and metastasis of esophageal squamous carcinoma through AMPK/STAT1/ULK1 signaling. J Cell Physiol 235: 2245-2259, 2020.

33. Chao YC, Pan SH, Yang SC, Yu SL, Che TF, Lin CW, Tsai MS, Chang GC, Wu CH, Wu YY, et al: Claudin-1 is a metastasis suppressor and correlates with clinical outcome in lung adenocarcinoma. Am J Respir Crit Care Med 179: 123-133, 2009.

34. Sheehan GM, Kallakury BV, Sheehan CE, Fisher HA, Kaufman RP Jr and Ross JS: Loss of claudins-1 and -7 and expression of claudins- 3 and -4 correlate with prognostic variables in prostatic adenocarcinomas. Hum Pathol 38: 564-569, 2007.

35. Emmanouilidi A, Paladin D, Greening DW and Falasca M: Oncogenic and non-malignant pancreatic exosome cargo reveal distinct expression of oncogenic and prognostic factors involved in tumor invasion and metastasis. Proteomics 19: e1800158, 2019.

36. Sun BS, Yao YQ, Pei BX, Zhang ZF and Wang CL: Claudin-1 correlates with poor prognosis in lung adenocarcinoma. Thorac Cancer 7: 556-563, 2016.

37. Mahati S, Xiao L, Yang Y, Mao R and Bao Y: miR-29a suppresses growth and migration of hepatocellular carcinoma by regulating CLDN1. Biochem Biophys Res Commun 486: 732-737, 2017.

38. Hoellen F, Waldmann A, Banz-Jansen C, Holtrich U, Karn T, Oberländer M, Habermann JK, Hörmann M, Köster F, Ribbat-Idel J, et al: Claudin-1 expression in cervical cancer. Mol Clin Oncol 7: 880-884, 2017

39. Zhang WN, Li W, Wang XL, Hu Z, Zhu D, Ding WC, Liu D, $\mathrm{Li} \mathrm{KZ}$, Ma D and Wang H: CLDN1 expression in cervical cancer cells is related to tumor invasion and metastasis. Oncotarget 7: 87449-87461, 2016.

40. Cunniffe C, Brankin B, Lambkin $\mathrm{H}$ and Ryan $\mathrm{F}$ : The role of claudin-1 and claudin-7 in cervical tumorigenesis. Anticancer Res 34: 2851-2857, 2014.

41. Zhou Y, Liu H, Wang J, Wang X, Qian L, Xu F, Song W, Wu D, Shen Z, Feng D, et al: $\Delta \mathrm{Np} 63 \alpha$ exerts antitumor functions in cervical squamous cell carcinoma. Oncogene 39: 905-921, 2020.

42. Soares $\mathrm{E}$ and Zhou $\mathrm{H}$ : Master regulatory role of $\mathrm{p} 63$ in epidermal development and disease. Cell Mol Life Sci 75: 1179-1190, 2017.

43. Hsiao YH, Hsieh MJ, Yang SF, Chen SP, Tsai WC and Chen PN: Phloretin suppresses metastasis by targeting protease and inhibits cancer stemness and angiogenesis in human cervical cancer cells. Phytomedicine 62: 152964, 2019.

44. Livak KJ and Schmittgen TD: Analysis of relative gene expression data using real-time quantitative PCR and the 2(-Delta Delta $\mathrm{C}(\mathrm{T}))$ method. Methods 25: 402-408, 2001.

45. Kuo KT, Chen CL, Chou TY, Yeh CT, Lee WH and Wang LS: $\mathrm{Nm} 23 \mathrm{H} 1$ mediates tumor invasion in esophageal squamous cell carcinoma by regulation of CLDN1 through the AKT signaling. Oncogenesis 5: e239, 2016.

46. Liebner S, Fischmann A, Rascher G, Duffner F, Grote EH, Kalbacher H and Wolburg H: Claudin- 1 and claudin-5 expression and tight junction morphology are altered in blood vessels of human glioblastoma multiforme. Acta Neuropathol 100: 323-331, 2000

47. Hammer SC, Nagel S, Junginger J, Hewicker-Trautwein M, Wagner S, Heisterkamp A, Ngezahayo A, Nolte I and Murua Escobar H: Claudin-1, -3,-4 and -7 gene expression analyses in canine prostate carcinoma and mammary tissue derived cell lines. Neoplasma 63: 231-238, 2016.

48. Feng S, Zhai J, Lu D, Lin J, Dong X, Liu X, Wu H, Roden AC, Brandi G, Tavolari S, et al: TUSC3 accelerates cancer growth and induces epithelial-mesenchymal transition by upregulating claudin-1 in non-small-cell lung cancer cells. Exp Cell Res 373: 44-56, 2018. 
49. Upmanyu N, Bulldan A, Papadopoulos D, Dietze R, Malviya VN and Scheiner-Bobis G: Impairment of the Gno11-controlled expression of claudin-1 and MMP-9 and collective migration of human breast cancer MCF-7 cells by DHEAS. J Steroid Biochem Mol Biol 182: 50-61, 2018.

50. Torres-Martínez AC, Gallardo-Vera JF, Lara-Holguin AN, Montaño LF and Rendón-Huerta EP: Claudin-6 enhances cell invasiveness through claudin-1 in AGS human adenocarcinoma gastric cancer cells. Exp Cell Res 350: 226-235, 2017.

51. Youssefian L, Vahidnezhad H, Saeidian AH, Sotoudeh S, Zeinali S and Uitto J: Gene-targeted next-generation sequencing identifies a novel CLDN1 mutation in a consanguineous family with NISCH syndrome. Am J Gastroenterol 112: 396-398, 2017.

52. Hu A, Li J, Ruan S, Fan Y and Liao Y: Polymorphisms in CLDN1 are associated with age and differentiation of triple-negative breast cancer patients. Biosci Rep 39: BSR20181952, 2019.

53. Tokés AM, Kulka J, Paku S, Szik A, Páska C, Novák PK, Szilák L, Kiss A, Bögi $\mathrm{K}$ and Schaff Z: Claudin- $1,-3$ and -4 proteins and mRNA expression in benign and malignant breast lesions: A research study. Breast Cancer Res 7: R296-R305, 2005.
54. Zhou B, Blanchard A, Wang N, Ma X, Han J, Schroedter I, Leygue $\mathrm{E}$ and Myal Y: Claudin 1 promotes migration and increases sensitivity to tamoxifen and anticancer drugs in luminal-like human breast cancer cells MCF7. Cancer Inves 33: 429-439, 2015.

55. Chen Yh, Lu Q, Schneeberger EE and Goodenough DA: Restoration of tight junction structure and barrier function by down-regulation of the mitogen-activated protein kinase pathway in ras-transformed Madin-Darby canine kidney cells. Mol Biol Cell 11: 849-862, 2000.

56. Lippoldt A, Liebner S, Andbjer B, Kalbacher H, Wolburg H, Haller $\mathrm{H}$ and Fuxe K: Organization of choroid plexus epithelial and endothelial cell tight junctions and regulation of claudin-1, -2 and -5 expression by protein kinase C. Neuroreport 11: 1427-1431, 2000

This work is licensed under a Creative Commons Attribution-NonCommercial-NoDerivatives 4.0 International (CC BY-NC-ND 4.0) License. 